\title{
Oncocytomas (oxyphil adenomas) of the lacrimal caruncle
}

\author{
I. G. RENNIE \\ From the Hallamshire Hospital, Glossop Road, Sheffield S10 $2 \mathrm{JF}$
}

SUMMARY Three cases of oncocytoma (oxyphil adenoma) of the lacrimal caruncle are reported. Transmission electron microscopy performed on one of the lesions confirms the tumour to be composed of cells containing abnormally large numbers of mitochondria. It is suggested that these tumours arise from accessory lacrimal glands or their secretory ducts.

Oncocytomas arising from the lacrimal caruncle are extremely uncommon tumours. It is generally accepted that Radnot's report ${ }^{1}$ was the first. She described an 'oncolytic cyst' which had been removed from the caruncle of a 69-year-old male. Since that report probably only 25 oncocytic lesions of the caruncle have been reported. These lesions have masqueraded under a variety of names, adding to the confusion which surrounds this lesion. They have been described as oncocytomas, ${ }^{2-7}$ oxyphil adenomas, ${ }^{89}$ papillary cystadenomas, ${ }^{10-12}$ adenolyphoma-like tumours, ${ }^{13}$ and Warthin's tumour. ${ }^{14}$ The author here reports 3 cases of caruncular oncocytoma and in addition comments on the transmission electron microscopic appearances and histogenesis of this curious lesion.

\section{Case reports}

\section{CASE 1}

The patient, a 73-year-old female, initially presented to the ophthalmic department in April 1975. She complained of reduced vision and pain in her right eye. On examination she was found to have a dendritic ulcer with secondary anterior uveitis; this was successfully treated with idoxuridine and atropine. In June 1977 she returned to the ophthalmic clinic complaining of photophobia and soreness of her eyes. She was found to have keratoconjunctivitis sicca, with positive staining of the cornea by rose Bengal, and a Schirmer's test showing reduced tear secretion (right eye $5 \mathrm{~mm}$, left eye $3 \mathrm{~mm}$ in $5 \mathrm{~min}$ ); she was treated with guttae methylcellulose.

In August 1977 she returned to the clinic for a routine follow-up visit. At this examination a swelling arising from the right lacrimal caruncle with numerous engorged blood vessels passing

Correspondence to Dr Rennie. over its surface was noted. On questioning, the patient disclosed that she had noted a small swelling of the inner part of her eye for the past 3 or 4 years. The lesion was excised and submitted for histology.

\section{Histological examination}

Macroscopic appearance. The specimen consisted of a nodule of brown tissue $5 \mathrm{~mm}$ in diameter.

Microscopical appearance. The tumour was composed of large polygonal, granular, eosinophilic cells. Two cell types were clearly discernible (Fig. 1). The first cell type had an intensely eosinophilic, homogeneous cytoplasm. These cells had a sharply angular configuration, with indistinct cell borders. The appearance suggested that they had been compressed by the second cell type present. The nuclei of this cell type were predominantly large, round or oval, with a prominant nucleolus. Occasional large 'atypical' nuclei were also present. Moreover, a few cells appeared binucleate. No mitotic figures were noted in the sections studied.

The configuration of this tumour was of a solid sheet of cells. However, occasional simple glandular structures were present, particularly at the periphery of the tumour. The tumour was encapsulated by a thin condensation of connective tissue.

Electron microscopy. Examination of the tumour by transmission electron microscopy confirmed the presence of large numbers of mitochondria within the cells. The distinction between light and dark cells appeared to be entirely due to the concentration of mitochondria within the cytoplasm. The mitochondria were morphologically abnormal, showing great variation in shape and size. Morphologically some of them were round or oval, while others were grossly elongated or fusiform in nature. Many contained densely packed longitudinal orientated cristae. This arrangement is identical to the para- 
Fig. I Case 1. A 'solid' oncocytoma showing distinct light and dark cells. Simple acinus formation is seen at the loft hand edge of the section. $(H \& E, \times 160)$.

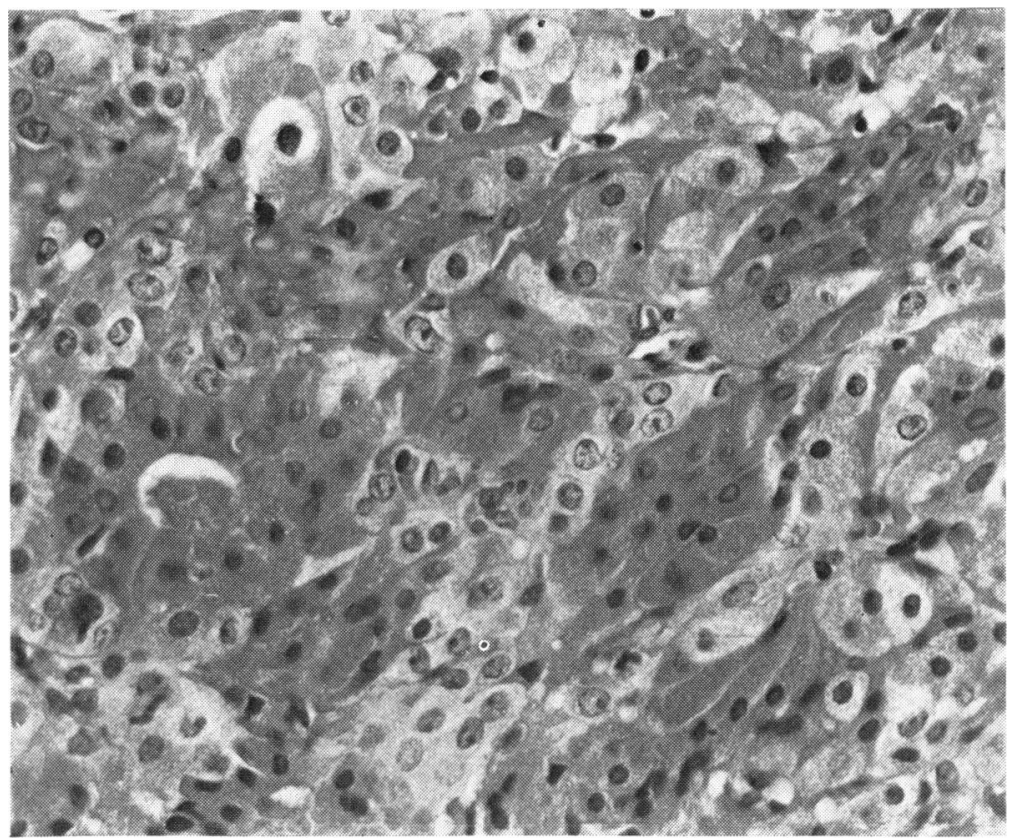

crystalloid bodies described in a caruncular oncocytoma described by Radnot and Lapis. ${ }^{5}$ Occasional desmosomes were noted between the tumour cells. Unfortunately, poor fixation precluded a more detailed examination by electron microscopy.

\section{CASE 2}

The patient, a 51-year-old female, presented at the ophthalmic clinic in February 1977 with a 20-year history of epiphora of the right eye. She stated that her tear duct had been 'pierced' many years previously. On examination the right nasolacrimal duct was found to be obstructed. In addition a papilliferous growth was present, arising from the right lacrimal caruncle. The lesion was excised and submitted for histological examination.

\section{Histological examination}

Macroscopic examination. Macroscopically the specimen consisted of a nodule of tissue measuring $4 \mathrm{~mm}$ in diameter.

Microscopical examination. Histologically the tumour consisted of epithelial cells arranged in a tubular papillary configuration (Fig. 2). In some areas the tubules formed large cystic spaces. In other areas the tubular configuration was not apparent, the cells forming a more solid structure. The tubules were lined by tall columnar, granular, eosinophilic cells. The nuclei were situated subterminally. Between the bases of the columnar cells smaller, rather indistinct, polygonal cells were present. These cells were similarly eosinophilic. The tubules were separated by a delicate stroma which contained capillaries. The nuclei showed little pleomorphism. Mitotic figures were not observed in the sections studied. Occasional mucus-secreting goblet cells were present in the epithelium; these cells stained strongly by the alcian blue method. The cystic spaces contained amorphous material which stained positively with the periodic acid Schiff and alcian blue methods.

The tumour was surrounded with a thin delicate capsule. In one section studied the epithelium of the tumour appeared in close apposition to the caruncular epithelium. The surrounding stroma of the caruncle contained hair follicles, sebaceous glands, and 2 accessory lacrimal glands. One of the glands contained simple secretory ducts. The epithelium of the ducts was composed of large granular eosinophilic cells similar to those in the tumour (Fig. 3). This presumably represented oncocytic metaplasia of the ductal epithelium. No communication between the gland and the metaplastic secretory ducts could be demonstrated.

\section{CASE 3}

The patient, a 74-year-old female, presented to the Ophthalmic Clinic in November 1964 with a history of gradual visual loss. Her visual acuity at that time was right eye $6 / 36$, left eye $6 / 24$. This was corrected to $6 / 18$ both eyes with a +1.5 dioptre sphere. On examination bilateral immature lens opacities were 


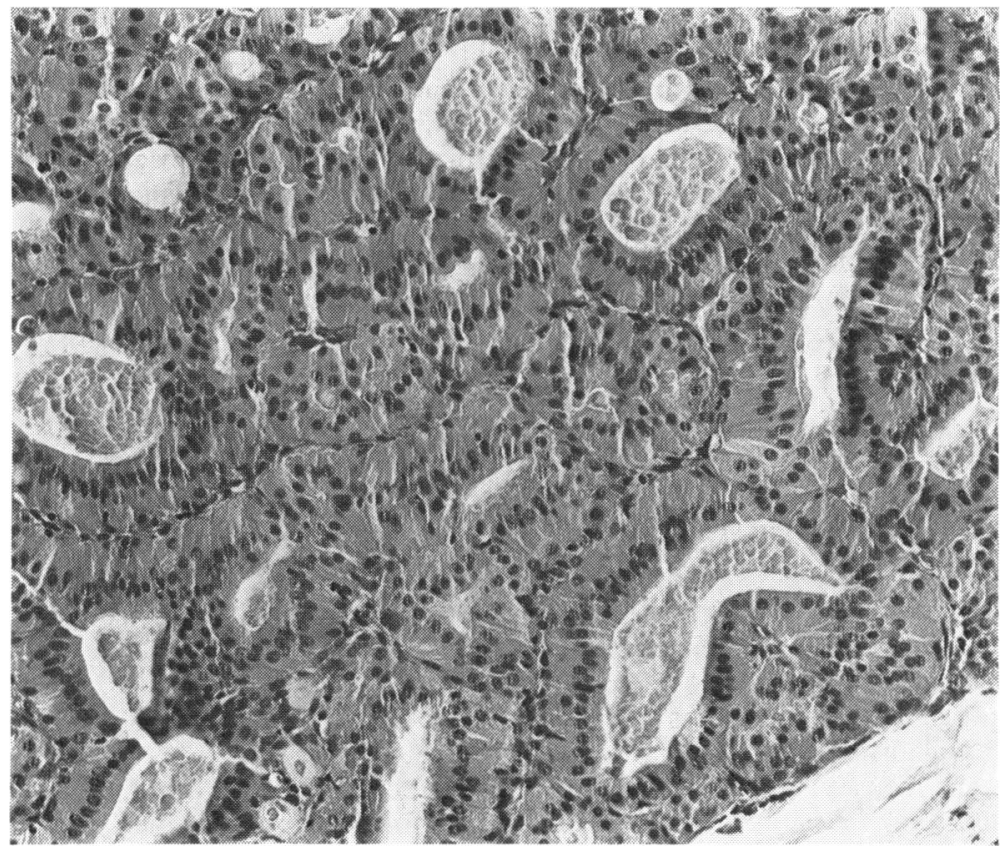

Fig. 2 Case 2. An oncocytoma with a pronounced papillary/ cystic configuration. Note the back to back formation of the oncocytes separated by a delicate stroma. $(H \& E, \times 60)$.

found. In addition a small cystic lesion of the right caruncle was noted. The patient stated that this lesion had been present for several years and was not causing any discomfort.

In October 1967 she attended the Ophthalmic Clinic again. Her visual acuity was now right eye $6 / 36$, left eye $5 / 60$; this was not corrected with lenses. The caruncular lesion was still present and was apparently unchanged in size. In April 1968 bilateral intracapsular lens extractions were per-

formed. Postoperatively her corrected visual acuity was 6/9 in both eyes. In December 1971 the patient attended the Ophthalmology Clinic again because the lesion of her right caruncle was increasing in size and now troubling her. The lesion was described as being a cystic swelling with several large blood vessels crossing its anterior surface. These appearances led to the tentative diagnosis of an angioma. The lesion was excised and submitted for histological examination.

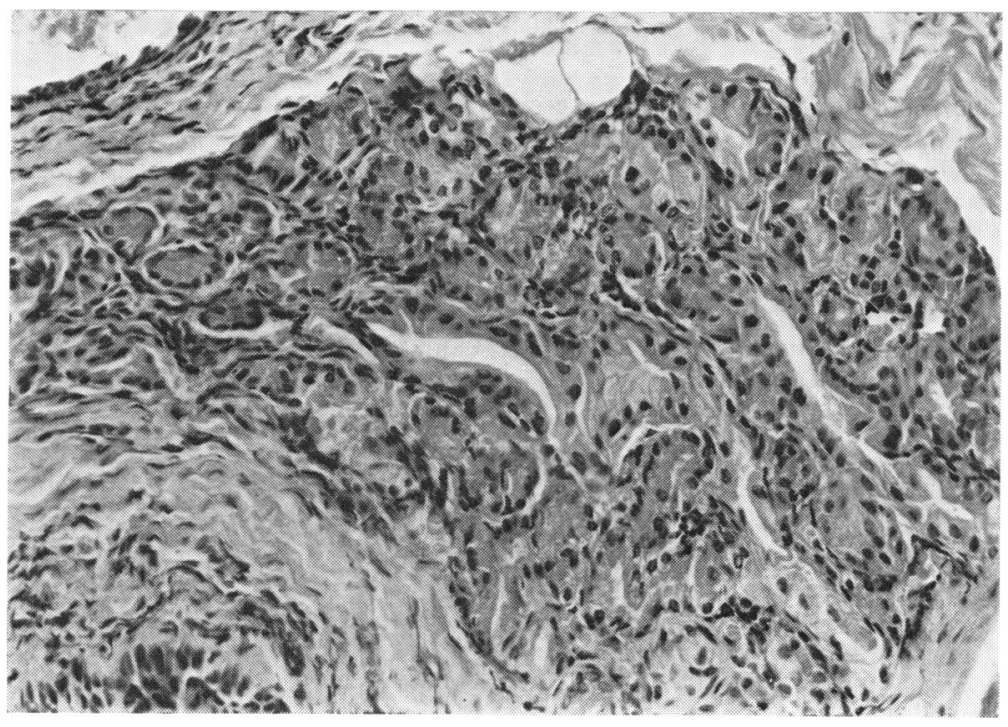

Fig. 3 Case 2. An accessory lacrimal gland containing $a$ secretory duct exhibiting marked oncocytic metaplasia, slightly right of centre. $(H \& E, \times 105)$. 


\section{Pathological examination}

Macroscopic appearances. The lesion was described as a ruptured cyst measuring $5 \mathrm{~mm}$ in diameter.

Microscopic examination. Histologically the cyst wall was composed of granular, intensely eosinophilic cuboidal cells forming a papillary-tubular structure. Occasional cells contained large brownish granules in their cytoplasm. These granules did not stain by any silver impregnation technique and were considered to be lipofuscin granules. Scanty mucus-secreting cells were present throughout the lesion. There was little nuclear pleomorphism, and mitotic figures were not identified in the sections studied. A scanty condensation of connective tissue surrounded the lesion.

\section{Discussion}

The term oncocyte was devised by Hamperl ${ }^{15}$ to describe an epithelial cell that was characterised by its large size and eosinophilic granular cytoplasm. The derivation of the term (Greek: Onkausthui-to swell) was thought by Hamperl to convey the essential morphological characteristic of the cell, namely its large swollen appearance. Electron microscopic studies ${ }^{516-18}$ (and case 1 of this report) have since shown that the essential feature of these cells is the number of mitochondria within the cytoplasm. It is believed that the increase in mitochondria in the oncocyte reflects a defect of metabolism in this organelle leading to a compensatory increase in their number. ${ }^{19}$ Though the primary metabolic defect is not known, it is thought to arise in old 'burnt out' cells, a concept inferred from the increasing incidence on oncocytic lesions with age.

Benign oncocytomas arising in ocular adnexa have been described in the lacrimal gland, lacrimal sac, plica semilunaris, bulbar conjunctiva, upper and lower fornices, mucocutaneous junction, and lacrimal caruncle. Of these, the caruncular oncocytoma is by far the commonest; however, even in this site it is a rarity. In a study of 200 lesions arising from the caruncle Evans ${ }^{20}$ described only 1 case which may have been an oncocytoma, the precise histological details being unavailable. Since that report probably only 25 cases (excluding this report) have been described.

Oncocytomas are generally regarded as benign tumours. However, sporadic reports of malignant oncocytomas have appeared. Malignant oncocytomas of the parotid have been described. ${ }^{21-23}$ One case arising from a gland in the nasal mucosa has also been described. ${ }^{19}$ Four malignant oncocytomas arising in ocular adnexa have been described, 2 arising in the lacrimal $\operatorname{sac}^{24}{ }^{25}$ and 2 occurring in the lacrimal gland. ${ }^{66}$ In relation to the lacrimal gland only 1 benign oncocytoma has been described. ${ }^{27}$ It is surprising that so few lacrimal oncocytomas (benign or malignant) have been described, especially when one considers the fact that oncocytic metaplasia is known to occur in this organ. Bock and Schlagenhauff ${ }^{28}$ examined the lacrimal glands of 20 necropsies and found oncocytic metaplasia in 7 of them (35\%). Equally surprising is the apparent excess of malignant tumours to benign lesions. It is possible to attribute these anomalies to the extremely slow growth of the benign oncocytoma.

Case 3 above illustrates the extremely slow growth of this tumour. The lesion was present for at least 7 years before excision. Thus benign lacrimal oncocytomas may never attain sufficient size to cause symptoms and thus escape detection. In contrast, a malignant lesion with its more rapid growth and invasion of adjacent tissues would be expected to produce symptoms.

\section{HISTOGENESIS OF CARUNCULAR \\ ONCOCYTOMAS}

The histogenesis of the caruncular oncocytoma is still open to discussion. Anatomically the lacrimal caruncle is a piece of modified skin. It is covered by stratified squamous epithelium and contains hair follicles, sebaceous glands, and sweat glands. It differs from skin in that it contains accessory lacrimal glands similar to those of Krause.

These glands are usually in the centre of the caruncle and open by a sinuous duct near the plica semilunaris. ${ }^{29}$ Three possible sites of origin are proposed-the surface epithelium, the conjunctiva, and the accessory lacrimal glands. Other suggested sites of origin such as sweat glands ${ }^{2}$ or mucous glands ${ }^{13}$ seem improbable, for oncocytomas are not described arising from these structures in other sites.

The accessory lacrimal glands or ducts have been proposed as the site of origin by several authors ${ }^{15610-12}$ in view of their histological appearances (see below). Greer ${ }^{8}$ described 2 cases of caruncular oncocytoma which appeared to arise from the surface epithelium. Case 2 above similarly showed close apposition to the surface epithelium. However, in this example oncocytic metaplasia was present in the duct of an accessory lacrimal gland present near the tumour, though a direct continuation between the 2 could not be demonstrated. Forbes and Crawford ${ }^{11}$ described a case in which a dilated secretory duct displaying oncocytic metaplasia was in direct continuity with an oncocytoma. A possible explanation for the existance of a lesion in apparent continuity with the surface epithelium as described by Greer $^{8}$ and the author (case 2) is that the lesion could have arisen from the epithelium 
of a secretory duct immediately beneath the caruncular epithelium. Briggs and Font ${ }^{6}$ described focal oncocytic metaplasia in the ducts and acini of accessory lacrimal glands present in the region of the caruncle. Radnot and Lapis $^{5}$ examined an oncocytoma with the transmission electron microscope and found, particularly at the periphery of the lesion, epithelial cells morphologically identical to those of accessory lacrimal glands. It would seem unlikely that oncocytomas arise from the caruncular epithelium proper, as this is a stratified squamous epithelium similar to skin, and, so far as the author is aware, oncocytomas have not been described arising from cutaneous structures elsewhere in the body.

It is possible that caruncular oncocytomas arise from the conjunctiva immediately adjacent to the caruncle. In support of this argument Briggs and Font ${ }^{6}$ described 2 oncocytomas apparently arising from the bulbar conjunctiva near the plica semilunaris. If oncocytomas were to arise mainly from the conjunctiva, then one should anticipate oncocytic changes described more frequently in the conjunctival epithelium, but this is not the case. Moreover, in relation to lesions described arising from the plica semilunaris, it is to be noted that this is the site of drainage of the secretory duct of the caruncular lacrimal tissue. It would appear that the majority, if not all, caruncular oncocytomas arise from accessory lacrimal glands or their secretory ducts. This belief is supported by the similar histological appearances of oncocytomas occurring at the caruncle and those occurring in other secretory glands, namely the major salivary glands.

\section{CLINICAL ASPECTS}

To the clinician the caruncular oncocytoma is a rarity. Nevertheless the diagnosis should be considered when he sees a caruncular swelling, particularly if the lesion appears cystic or has a bright cherry red colour. The lesion appears to occur mainly in postmenopausal females. In the 28 cases recorded, including this report, 5 patients have been male (in one case the sex of the patient was not given), a ratio of $5 \cdot 6: 1$ females to males. It usually has an extremely slow rate of growth and often presents as a chance finding.

The author thanks Miss M. A. C. Jones and Mr C. A. L. Palmer for allowing the publication of their clinical material; Professor L. Henry and Mr A. Stanworth for their help and encouragement; Miss F. Bishop and Mrs S. Porter for their assistance with the technical preparation of the specimens.

\section{References}

1 Radnot M. Seltene Geschwulste der Caruncula lacrimalis. Ophthalmologica 1947 ; 113: 270-5.
2 Noguchi TT, Lonser E.R. Oncocytoma (oxyphil-cell adenoma) of the caruncle of the eyelid. Arch Pathol 1960; 69: 516-9.

3 Klein HJ. Zystisches Onkozytom der caruncula lacrimalis. Klin Monatsbl Augenheilkd 1965; 146: 343-8.

4 Deutsch AR, Duckworth JK. Onkocytoma (oxyphilic adenoma) of the caruncle. Am J Ophthalmol 1967; 64: 458-61.

5 Radnot $M$, Lapis $K$. Ultrastructure of the caruncular oncocytoma. Ophthalmologica 1970; 161: 63-77.

6 Briggs SL, Font RL. Oncocytic lesions of the caruncle and other ocular adenexa. Arch Ophthalmol 1977; 95: 474-8.

7 Nemeth B, Feher J. Oncocytoma carunculae. Ophthalmologica 1977; 175: 1-4.

8 Greer $\mathrm{CH}$. Oxyphil adenoma of the lacrimal caruncle. Br J Ophthalmol 1969; 53: 198-202.

9 Dhermy P, Offret K. Adenome oxyphile à cellules granuleuses (oncocytome) de la caroncule. Arch Ophtalmol (Paris) 1976; 36: 51-8.

10 MacKenzie JR, Patience CR. Papillary cystadenoma of the lacrimal caruncle. J Pathol Bacteriol 1959; 78: 288-4.

11 Forbes GB, Crawford RAD. Papillary cystadenoma of lacrimal caruncle. Br J Ophthalmol 1963; 47: 177-9.

12 Wilkerson JA, Winquist WD. Bilateral papillary cystadenoma of the lacrimal caruncle. Arch Pathol 1969; 88: $540-52$.

13 Lennox B, Timperley WR, Murray D, Kellet HS. Adenolymphoma-like tumours of the lacrimal caruncle on the larynx. J Pathol Bacteriol 1968; 96: 321-6.

14 Oaks LW, Jenson MB. Warthin's tumour; papillary cystadenomalymphoma occurring in a human caruncle. Am J Ophthalmol 1963; 56: 459-61.

15 Hamperl M. Onkocyten and Geschwulste der Speicheldrusen. Virchows Arch (Pathol Anat) 1931; 282: 724-36.

16 Tandler B, Shipkey F. Ultrastructure of Warthin's tumour. J Ultrastruct Res 1964; 11: 292-305.

17 Balogh K, Roth SI. Histochemical and electron microscopic studies of eosinophilic granular cells (oncocytes) in tumours of the parotid gland. Lab Invest 1965; 14: 310-8.

18 Tandler B, Hutter RVP, Erlandson RA. Ultrastructure of oncocytoma of the parotid gland. Lab Invest 1970; 23: $567-80$.

19 Hamperl $\mathbf{H}$. Benign and malignant oncocytoma. Cancer 1962; 15: 1019-27.

20 Evans WM. Tumours of the lacrimal caruncle; a study of 200 collecied cases. Arch Ophthalmol 1940; 24: 83-106.

21 Bauer WH, Bauer JD. Classification of glandular tumours of salivary glands; study of 143 cases. Arch Pathol 1953; 55: 328-46.

22 Buxton RW, Maxwell JH, French AJ. Surgical treatment of epithelial tumours of the parotid gland. Surg Gynecol Obstet 1953; 97: 401-16.

23 Eneroth CM. Oncocytoma of major salivary glands. J Laryngol Otol 1965; 79: 1064-71.

24 Ryan SJ, Font FL. Primary epithelial neoplasms of the lacrimal sac. Am J Ophthalmol 1973; 76: 83-8.

25 Peretz WL, Ettinghausen SE, Gray GF. Oncocytic adenocarcinoma of the lacrimal sac. Arch Ophthalmol 1978; 96: 303-4.

26 Dorrello U. Carcinoma oncocitoria della ghiondola lacrimale. Riv oto-neuro-oftalmol 1961; 36: 452-61.

27 Beskid M, Zorzycha M, Przypadek onkocytoma graczolo lzowego. Klin Oczna 1959; 29: 311-5.

28 Bock J, Schlagenhauff K. Uber das Vorkommen von Onkozyten in der menschlichen Trankudruse. $Z$ Augenheilkd 1938; 94: 224-55.

29 Wolff E, revised Warick R. Anatomy of the Eye and Orbit. 7th ed. London: Lewis, 1976: 219-200. 